Vol. No. 1, Issue No. 1, December, 2017,43-53

Copyright (C) IIUM Press

eISSN 2600-8432

\title{
The Significance of Religious Key Terms and Their New Meanings in Al-Faruqi's Al-Tawhīd: Its Implications for Thought And Life
}

\author{
Fadzilah Din ${ }^{*}$
}

\begin{abstract}
One of the most brilliant contributions of Ismail Raji al-Faruqi (19211986) is his writings in the field of Islamic Thought. His masterpiece AlTawhid: Its Implications for Thought and Life is indeed a great and refreshing contribution to the modern Islamic Worldview. This article discusses selected traditional religious terminologies which have been redefined by al-Faruqi in his Al-Tawhid thus given new meanings, and implications. The selected terms taken from Al-Tawhid and analysed in this article are ilāh, tawhīd, ìmān, 'ibādah and ummah. The old meanings of these terms are compared with the new ones. Much positive ethical implications to Islamic practice can be discerned from the new meanings of the terms analysed. The new meanings of these terms contribute more positively to the practice and understanding of Islam to the new generation in a relevant and beneficial way in our modern time and society.
\end{abstract}

Keywords: Islamic Thought, Islamic Worldview, Islamic religious terms, al-Faruqi, Al-Tawhìd.

\section{Introduction}

Al-Tawhìd: Its Implications for Thought and Life was published by Ismail Raji al-Faruqi in $1982 .{ }^{1}$ This book is considered a masterpiece in modern Islamic theology for many Muslims. In it, the writer elaborates the significance of al-Tawhi d (absolute monotheism) and its implications in a new and distinctive way. The author relates the concept of Tawhìd to the principles of History, Knowledge,

\footnotetext{
* Dr.Fadzilah Din is Assistant Professor, Department of Usuludin and Comparative Religion, Kulliyyah of Islamic Revealed Knowledge and Human Sciences, International Islamic University, Malaysia (IIUM). Email: Fadzilah@iium.edu.my ${ }^{1}$ The one referred in this article is Ismail Raji al-Faruqi, Al-Tawhid: Its Implications for Thought and Life, (Herndon, Virginia: The International Institute of Islamic Thought, 1992), henceforth referred to as Al-Tawhid.
} 
Metaphysics, Ethics, Social Order, the Ummah, Family, Political Order, the Economic Order, and Aesthetics, which is remarkable and has never been done before. He emphasizes that Tawhìd as a foundation of Islam, Islamic culture and Islamic civilization in essence is knowledge-based. It is also important to note that according to al-Faruqi, Muslims developed the science of 'ilm al-tawhìd under which disciplines such as: logic, epistemology, metaphysics and ethics are its constituents. ${ }^{1}$ In another place, he mentions that even Aesthetic subsumes under 'ilm altawhi $\bar{l} .^{2}$ This article analyses the new meanings and explanations to the traditional ordinary Islamic religious terminologies in the book mentioned above. Perhaps a more correct way of stating it is that alFaruqi gives a correct meaning to religious terminologies which has been distorted over many centuries, thus making them properly comprehensible again.

There is a special need for Muslims to understand these religious terminologies correctly because the deviation among Muslims from the truth in Islamic epistemology has caused "widespread deviations among Muslims in their thinking modes from established norms rooted in traditional Islamic intellectual culture." 3 Agreeing with that statement, this author elucidates a number of common religious terminologies such as ilāh, tawhìd, ìmān, 'ibādah, amānah and ummah, in which al-Faruqi have mentioned and blew a new breath of understanding. Previously, these terms have been understood in their traditional religious usage which causes a certain misunderstanding, and has become problematic for Muslims, irrespective of age groups, with regard to the correct understanding of Islam, and thus resulted in a substandard practice of their religion. The problem was precisely a separation of belief and ethics as explained below.

\section{Ilāh}

The common meaning for the term ilāh is god with a small "g". It can also mean idol. In Malay, ilāh is usually translated as "tuhan". Therefore, in the first part of the confession of faith, Là ilāha illa 'llāh, is usually translated as Tiada tuhan melainkan Allah. In English, this would be "There is no god but Allah" or "There is no god but God".

\footnotetext{
${ }^{1}$ Ibid., 17.

${ }^{2}$ Ismail Raji Al-Faruqi, The Cultural Atlas of Islam. (New York: Mcmillan,1986).

${ }^{3}$ Osman Bakar, Islamic Civilization and the Modern World, (Brunei Darussalam: UBD Press, 2014), 41.
} 
Both the Malay and the English translations refer to the message that there is only one God, the latter English translation "There is no god but God" can be rather confusing for some. Whenever mentioned in a classroom that uses English as a medium of instruction, for instance, it has to be pointed out verbally for example, "There is no god [in small g] but God [capital G]". When we look at the book Al-Tawhid, we find that al-Faruqi translates ilāh as "an object of desire." ${ }^{1}$ The significance of this shift, i.e., translating "ilāh" as "an object of desire", is very helpful and clarifies a number of misunderstandings and confusions about the concept of God in Islam. Thus, the meaning of "lā ilāha illā 'llāh" now becomes, "there is no object of desire but Allah (God)", or to be more literal, "there is no object of desire other than The Ultimate Object of all Desire, i.e., God", because the term "Allah" comes from al-ilāh. Hence, when someone says, lā ilāha illā 'llāh, he means, "there is no other object of desire (for him) other than God (the ultimate object of all desire)". For those who understand, lā ilāha illā 'llāh is an ethical statement.

The implication of that statement is, his object of desire will be God alone, not other objects of desire such as personal interest in money, power, fame, family, career, national interest, or any other interests which are not ethical. This is because God is ethical in Islam. Among His 99 beautiful names (al-Asmā' al-ḥusnā), Justice (al- 'Adl) and Truth (al-Haqq) ${ }^{2}$ are included. God commands only what is good, whereas his names depict the ethical principles. That is not to say that we should not desire money, power, fame, family, career, national interest, and other interests, but it should be remembered that they are only tools to be used to do good for oneself and further the progress of humanity. They are not the ultimate goals in themselves. This is also

\footnotetext{
${ }^{1}$ Al-Faruqi, Al-Tawhid, 2.

2 See al-Qur'an, 4:58 'God commands you to render the Trusts to those they are due and when you judge between men, judge with Justice. Excellent indeed is the teaching He has given you. For God hears and sees all things". See also al-Qur'an 4: 135, "O Believers! Stand out firmly for justice as witnesses to God even if it be against yourselves, or your parents, or your kin, and whether it be against the rich or poor: for God is Highest. Do not follow your lusts lest you swerve. If you distort or decline to do justice, God knows everything that you do". Al-Qur'an 22:62, "That is because God is the Truthwhile those other than Him that they invoked are Falsehood. God is He who is Most High, Most Great. See also Robert Stade, Ninety-nine Names of God, (Ibadan: Daystar Press. 1970).
} 
important because more often than not, many Muslims think as long as they are not worshipping other gods, i.e., Jesus, any Hindu gods, a carved object or sculpture, they are doing the right thing and are still tawhidic. Thus, many do not see that committing acts of corruption, injustice, lying, untruth, harming others etc., as taking other gods as an object of desire other than God. In such cases, they do not realize that they have taken the ethics out of their declaration of faith.

\section{Tawhịd}

Tawhid, which is the foundation of Islam, has also suffered distortion of meaning and implications among Muslims. Tawhid means unity of God. Conceptually, it is supposed to promote an uncompromising monotheism. ${ }^{1}$ It is not merely about believing or worshipping only one God.

The concept of Tawhid is derived from understanding the implication of "là ilāha illa 'llāh" i.e., that there is no other God but the One who is the Creator of everyone and everything. The most important implication of the One God and Creator should be the Oneness or Unity of creation, and therefore Oneness or Unity of humanity. The realization of this concept is very much related to ethical behaviour. If God is the only Creator and He is Good, then all are equal in the sight of God. Equality of man means justice for all and that one would give others the same dignity as one expects to receive. We may use an example of ethnocentrism to clarify.

According to al-Faruqi, "when ethnicity become ethnocentrism, Islam condemns it as kufr [apostasy]." 2 This statement is rarely heard

\footnotetext{
${ }^{1}$ This is in opposition to the Christian concept of trinity which although recognized as monotheism by Christians, is considered as tritheism in Islam. Qur'ān 4:48 can be used to justify this claim. The verse reads, "Allah does not forgive any ascription of associates to Him, but He forgives all other offenses to whomsoever He wills. Whoever, ascribe partners to Allah has committed sin most heinous". However, an article by C. John Block, 2011mentions that there was a misconception that trinity is the same as tritheism among Muslims due to their early exposure to monophysitism trend in Najran. Block, C. John. (2011). "Philoponian Monophysiticm in South Arabia at the Advent of Islam with Implications for the English Translation of 'Thalattha' in Quran 4.171 and 5.73”. Retrieved from http://www.scribd.com/doc/75903409/PHILOPONIAN-MONOPHYSITISM-IN-SOUTHARABIA-AT-THE-ADVENT-OF-ISLAM-WITH-IMPLICATIONS-FOR-THE-ENGLISHTRANSLATION-OF-THAL2THA-IN-QUR82N-4-171-AND-5-7

${ }^{2}$ Al-Faruqi, Al-Tawhid, 106.
} 
and almost unknown until recently. That ethnocentrism or racism constitutes no part in Islamic theology and is based on the concept of One God is still surprising for many. This is largely due to a misunderstanding or nonunderstanding of the implication of the unity of God as mentioned earlier. The idea that there is only One God means, there is only one humanity since $\mathrm{He}$ is the Creator of everyone and everything. By being racist or ethnocentric, one has denied that the One Creator has also created the other by denying the same rights, dignity and humanity of the other. In other words, being ethnocentric or racist is kufr by virtue of making one's ethnicity or race a superior entity next to God or raising one's ethnicity or race as one's iläh. In Islam, thinking about God results in ethical ideas and should transform into ethical behaviours because part of understanding Tawhìd is to understand the beautiful names and attributes of God or Tawhìd al-Asmā' wa al-Sifät, which include Truth, Justice, Compassion, Possessor of Knowledge, Benevolence and Beauty, among others.

Among the contribution of al-Faruqi in al-Tawhid, is his elaboration of the worldview behind it. He discusses the tawhidic worldview and arranged it in a way that none before him did. Al-Faruqi explains that there are five (5) principles underlying the tawhidic worldview by using these terminologies: Duality, Ideationality, Teleology, Capacity of Man and Malleability of Nature, and Responsibility and Judgement. ${ }^{1}$

By Duality, he means that Reality is dual. It consists of God and non-god. That God can only be God and the rest are His creations. God cannot "be united with, infused, confused with or diffused into the creature." 2 The significance of understanding this tawhidic principle is that people will not be easily led into believing that any creatures or objects is divine or infused with divinity as many have done including Muslims, which create irrational beliefs.

By Ideationality, al-Faruqi means that the relationship between God and Man, and Creation, can be understood rationally. There is no need to explain the relationship between God and Man through the use of symbolism and mystery. Humans are endowed with understanding. Rational explanation will make an idea acceptable to everyone, not just among a very particular adherent.

\footnotetext{
${ }^{1}$ Al-Faruqi, Al-Tawhid, 10-15.

${ }^{2}$ Al-Faruqi, Al-Tawhid, 10.
} 
By Teleology, the author means that the universe and everything in it are created to serve their purposes. Everything fulfils a purpose and there is a cause and effect behind Nature. There are utilitarian aspects to natural laws which can be fulfilled by freewill when the purposes are understood. Science cannot function if the same causes do not produce the same result. Understanding them is necessary to serve humanity and promote advancement, either in sciences and technology or in human sciences such as sociology, psychology, etc.

Related to Teleology, Capacity of Man and Malleability of Nature, al-Faruqi tries to explain that humans are given capacity and freedom to act or not to act, and Nature is malleable enough to receive this act. Related to the idea of Teleology, Capacity of Man and Malleability of Nature support the belief in the freedom of human action, the ability to change the world, the importance of knowledge and the utility of reason. Thus, the principle ties in neatly with the last principle which is Responsibility and Judgement. With the capacity of man to act or not to act, there are consequences. Therefore, humankind must take a moral responsibility and proper judgement upon all their actions because of the physical implications that moral failure entails.

It is interesting and most apt that principles in modern Islamic theology should include ideas that are universal, rational, discussion of moral-ethical conduct, freedom of action, how nature works and their implications. This newness in looking at and understanding al-Tawhīd as a concept challenges the dogmatic ideas of Islamic beliefs which were not supposed to be dogmatic in the first place.

\section{$\bar{I} \boldsymbol{m} \bar{a} \boldsymbol{n}$}

Another religious terminology that has been misunderstood is $\bar{\imath} m \bar{a} n$. Imān has been understood as faith or belief for a very long time. Most people laymen and even Muslim clergy has not related or connected $\bar{i} m \bar{a} n$ with the cognitive process. In fact, there is a group of religious people who claim that matters concerning religion must not be questioned, let alone religious dogmas such as pillars of faith (arkān al$\bar{i} m \bar{a} n)$. Al-Faruqi, however, argues and proves that translating $\bar{\imath} m \bar{a} n$ as faith or belief is wrong. He allocates a whole chapter titled "The Principle of Knowledge" to explain this very important concept. He mentioned that the English words "faith" and "belief" today carry the implication of untruth, of probability, of doubt and suspicion which is 
the exact opposite of the meaning of $\bar{\imath} m \bar{a} n$. He made a very important point by stating that from an etymological point of view,

"[T] he term imañ deriving from a $m n$ (security), means that the propositions it covers are in fact true, and that their truth has been appropriated, (i.e., understood and accepted) by the mind...imān cannot be false in the sense that its object is nonexistent or otherwise than it purports to say... It is not an act, not a decision, not a resolution to accept, or puts one's trust in, that which is not known to be true...imān is something that happens to man, when the truth, the factuality of an object strikes him in the face and convinces him beyond doubt of its truth.." 1

Therefore, imān also means the state of being secure because of one's knowledge of the truth of the matter which, like any other knowledge, requires evidence. Based on the argument by Al-Faruqi, I conclude that the concept of $\bar{i} m \bar{a} n$ is thus cognitive, scientific, logic and devoid of the "hocus-pocus" which common people find very attractive, and think that for something to be religious, it must be irrational. This very understanding of $\bar{i} m \bar{a} n$ will lead to scientific and rational thinking because it is based on reality, not dogma. That belief in God and the unseen is demonstrable by rational arguments, and therefore the result should be that a knowledgeable person is a person who has imañn. AlFaruqi clarifies further by saying that:

"imān is truth given to the mind, not to man's credulity. The truths, or prepositions, of imān are not mysteries, stumbling blocks, unknowable and unreasonable but critical and rational. They have been subjected to doubt and emerged from the testing confirmed and established as true. No more pleading on their behalf is necessary." 2

All this is important to understand the meaning of imann, the true meaning of which Muslims have forgotten, or have conveniently distorted. Translating im $\bar{a} n$ as belief, or percaya in Malay, has resulted in the Islamic religion becoming no more than a dogma, and thus leading Muslims to fall prey to irrational beliefs. Imān in essence is

\footnotetext{
${ }^{1}$ Al-Faruqi, Al-Tawhid, 40-41.

${ }^{2}$ Al-Faruqi, Al-Tawhid, 41.
} 
proven knowledge. In other words, since $\bar{i} m \bar{a} n$ is derived from the root amn which means security, the proper meaning of $\bar{i} m \bar{a} n$ is security due to the possession of knowledge.

\section{'Ibādah}

The concept of 'ibadah is very essential in Islam. A loose translation of 'ibādah is worship. While the underlying meaning of 'ibadah is to render service, but it is worship that is mostly understood by the common people. Its basis is Surah 51: 56, in which the famously oft-repeated verse reads, "I have not created jinn and mankind except to serve (which can also be translated as worship) Me."1 Although alFaruqi does not elaborate much on the concept of "ibādah, his personal translation of the word ya 'budūni as "serve me" instead of "worship me" is very telling. For herein lays the confusion among Muslims both in concept and in practice.

In practice, 'ibādah has always been understood as worship rather than rendering services. Thus, 'ibādah is still largely understood as ritual prayers, fasting, charity, performing Hajj, slaughtering of animals, chanting the Qur'ān, and dhikr; all of which are ritualistic in nature. This means the idea that "to worship God is to do good to His creatures" or "to serve humanity", or in the words of al-Faruqi, "the purpose of man's existence is the realization of the summum bonum (the highest good)", has not fully taken root among the masses. ${ }^{2}$ Thus, we suffer the bad attitude towards work and the prevalent paralysis of social institutions in Islamic societies because work and services are not seen as meritorious services to God even though the idea has been preached. While the idea that all good works are equated to worship or serving God is not totally alien, in practice the concept has been slow to be properly internalised. While other nations invent new institutions or improve the old ones, and invent new machinery to improve the lives of fellow humans, the Muslim ummah continue to be negligent and careless towards the fate of their fellow men. Similarly, other human qualities such as kindness and compassion, politeness and helpfulness, are not qualities that Muslims are well known for at present due to overemphasis in ritual observance. Therefore, we have people who pray, fast, give charity, performing Hajj, slaughtering of animals, chanting the Qur'ān, and perform verbal dhikr Allāh (remembrance of Allah), who

\footnotetext{
${ }^{1}$ Al-Faruqi, Al-Tawhid, 18.

${ }^{2}$ Al-Faruqi, Al-Tawhid, 66.
} 
have no qualms about denying human rights, cheating others, being involved in corruption and injustice, mismanagement of public funds and properties, and many others.

\section{Amānah}

It has been mentioned in the Qur'ān that God created man and the jinn in order to serve Him. ${ }^{1}$ To this end, it has been mentioned that to serve God is equal to worshipping Him. Can there be worship or service to God without the ethical dimension of amānah? Amānah, like $\bar{i} m \bar{a} n$, is derived from the same root $a, m, n$ which means security. While imān means to be secure with knowledge, amānah means to be secure from irresponsibility. Al-Faruqi's discussion of amānah is to show its importance in the tawhidic paradigm. Quoting verse 33:72, which reads, "We have offered Our trust to the heavens and the earth and the mountains. But they were frightened by and refused to carry it. Man however accepted and carried it". He argues that amānah means ethics or moral responsibility. He said, "The divine trust is the fulfilment of the ethical part of the divine will, whose very nature requires that it be realized in freedom, and man is the only creature capable of doing so." ${ }^{2}$ The traditional translation of amānah is trust; which many find it vague. Redefining amānah to mean moral responsibility is more precise and emphasizes the importance of ethics in the concept of Tawhid. Furthermore, it is easier to grasp why it is important to be virtuous if one believes in the tawhidic concept. The concept of ibadah and amānah are unambiguous, inclusive, and related to each other according to al-Faruqi's explanation.

\section{Ummah}

While the term ummah does not differ much in application and meaning, as used either by traditional Muslims or Al-Faruqi, this concept, by al-Faruqi's own argument, seems to be leading to the conclusion that all those who believe in the Islamic worldview and morality and willing to work together to achieve the highest good, are one ummah. For example, he states that "the ummah is translocal, not determined at all by geographical considerations..." 3 The ummah is

\footnotetext{
${ }^{1}$ Al-Qur'ān, 51:56.

${ }^{2}$ Al-Faruqi, Al-Tawhid, 61.

${ }^{3}$ Al-Faruqi, Al-Tawhid, 105.
} 
" "not synonymous with "the people", or "the nation" or "the state." 1 "the ummah is a truly universalist brotherhood in which all men are members, potentially by virtue of birth, and actually by virtue of a free personal, ethical decision to enter into the world-fellowship of the law." In another place, he states that all men are one and measurable only in terms of piety. He quoted the Quranic verses 49:13 "O mankind, we have created you male and female and made you into nations and tribes that you may know each other. Indeed, the most honoured of you in the sight of God is the most righteous of you. And God has full knowledge and well acquainted with all things".

We are in need to understand why, despite all the arguments above, al-Faruqi insists on separating or dividing humanity by religion even though the Charter of Medina indicates that the ummah included the Jews too. The Charter of Medina clearly states twice, the inclusion of Jews as one ummah with the Muslims in the first and twenty-fifth clauses of the Charter and further elaborates their duties and responsibilities mentioning all the Jewish tribes involved. The Charter also illustrates that the Jews and the Muslims have equal rights. ${ }^{3}$ In fact, the verse quoted above is more in line with the Charter of Medina than the concept of separation of people by religion where people, who adhere to common moral and ethical values, are more rightly to be considered as one. Therefore, to use the term ummah to refer to the Muslims as a collective is clearly a political decision rather than religious. In the $21^{\text {st }}$ century, in the spirit of pluralism, or at least inclusivity, for those who think pluralism is a dirty word just like they do with secularism and liberalism, perhaps the term ummah might be more suitable to indicate people who share the same aspirations and values who are working towards the highest good. This is true because good Jews, Christians, Muslims, Buddhists, Hindus, Atheist, Agnostics etc., are more like each other in their ethical understanding and practice. Likewise, there is no difference between haters from any religions and of the secular persuasions.

\footnotetext{
${ }^{1}$ Al-Faruqi, Al-Tawhid, 105.

2 Al-Faruqi, Al-Tawhid, 119.

3 Ahmed, Nazir. (2013). The Charter of Madina: the first written Constitution of the world. Retrieved from http://www.parisvisionnews.com/religion/132-islam/8511-thecharter-of-madina-the-first-written- constitution-of-the-world.html
} 


\section{Conclusion}

The approach that Al-Faruqi has taken in redefining and reexplaining the terminologies such as ilāh, tawhìd, imāan, 'ibādah, amānah and ummah is very deliberate although veiled behind other complex topics and issues, while its importance cannot be overemphasized. It has helped many students to understand Islam more nuancedly because the explanations of these terminologies, albeit complex, are directly linked to their implications to human thoughts and behaviour. The reason that Muslims' understanding of Islam has stagnated to dogmatic conservatism is precisely caused by the misunderstanding of these important terminologies.

\section{References}

Ahmed, Nazir. (2013). "The Charter of Madina: the first written Constitutionof the world." Retrieved from http://www. parisvisionnews.com/religion/132islam/8511-the-charter-of-madina-the-first-written-constitution-of-theworld.html

Al-Faruqi, Ismail Raji. Al-Tawhid: Its Implications for Thought and Life, (Herndon,Virginia: The International Institute of Islamic Thought,1992).

Al-Faruqi, Ismail Raji. The Cultural Atlas of Islam, (New York: Mcmillan. 1986).

Ali, A. Yusuf. The Holy Qur'an: Text, and Commentary. (Leicester: The Islamic Foundation, 1975).

Bakar, Osman, Islamic Civilization and the Modern World, (Brunei Darussalam: University Brunei Darussalam Press, 2014).

Block, C. John. (2011). "Philoponian Monophysiticm in South Arabia at the Advent of Islam with Implications for the English Translation of 'Thalātha' in Quran 4.171 and 5.73”. Retrieved from http://www.scribd.com/doc/75903409/PHILOPONIAN-MONOPHYSITISMIN-SOUTH-ARABIA-AT-THE-ADVENT-OF-ISLAM-WITHIMPLICATIONS-FOR-THE-ENGLISH-TRANSLATION-OF-THAL2THAIN-QUR82N-4-171-AND-5-7

Stade, Robert, Ninety-nine Names of God, (Ibadan: Daystar Press, 1970). 
